\title{
Modelling the Relationship among Green Perceived Value, Green Trust, Satisfaction, and Repurchase Intention of Green Products
}

\author{
Aris Y. C. Lam \\ Hong Kong Polytechnic University \\ E-Mail: sparis@speed-polyu.edu.hk \\ Mei Mei Lau \\ Hong Kong Polytechnic University \\ E-Mail: spmay@speed-polyu.edu.hk \\ Ronnie Cheung \\ University of South Australia \\ E-Mail: ccheung@acm.org
}

\begin{abstract}
This study investigates the relationship among green perceived value, green trust, satisfaction, and repurchase intention of green products. A research model was developed to investigate the factors affecting the repurchase intention of green products. The research results demonstrated that green trust and satisfaction mediate the relationship between green perceived value and repurchase intention. The research results also indicated that the drivers of green product repurchase intention are represented by perceived value, green trust, and satisfaction. Companies should emphasize resources to improve these aspects in order to enhance green product repurchase intention among consumers.
\end{abstract}

Keywords: Green Products, Repurchase Intention

\section{INTRODUCTION}

Economic activities have been using up resources from the planet at an alarming rate. Consumption is more and more clearly seen to be creating harmful effects on the natural environment (Koller, Floh, \& Zauner, 2011). Scientists and environmentalists have repeatedly warned governments that our planet has been in environmental turmoil for the past few decades. Some have said that the solution to saving our planet 
is to go green in our living. As more people become aware of the problem of global warming, more consumers become eager to engage in "green consumption" (Whitmarsh, 2009). Eco-friendly or green products are welcomed by consumers as they help preserve the natural environment and reduce the pollution and degradation of our planet. More companies have realized new business opportunities and started to take advantage of the relatively new trend of green marketing or sustainability marketing, which is the "effort made by business organizations to design and promote products that are eco-friendly" (Choudhary \& Gokarn, 2013). These companies focus on the development of green marketing, which is about developing strategies that can generate profits for companies while being able to sustain, protect, and preserve the environment (Kotler \& Armstrong, 2013).

\section{LITERATURE REVIEW AND HYPOTHESIS DEVELOPMENT}

\section{Green Marketing and Competitive Advantage}

In the era of global warming, environmental consideration in consumption has become widely accepted by consumers, and more consumers are paying attention to green products (Chen \& Chang, 2012). With the heightened awareness of environmental concerns, consumers are eager to purchase more green products (Kalafatis, Pollard, East, \& Tsogas, 1999), which are perceived to be not as harmful to the environment (Chen, 2010). Green products are able to command a premium price; for example, $83 \%$ of Brazilians, $93 \%$ of Thai, and 53\% of Americans are willing to pay more for the purchase of green products (Makower, 2009). As a result, green products have become a powerful weapon in building a competitive advantage because more consumers are willing to pay a higher price for green products (Bhat, 1993).

Green marketing is defined as "the holistic management for identifying, anticipating and satisfying the requirements of customers and society, in a profitable and sustainable way" (Peattie, 1998). It is also defined by the American Marketing Association in three aspects - namely, "the marketing of products that are presumed to be environmentally safe" (retailing), "the development and marketing of products designed to minimize negative effects on the physical environment or to improve its quality" (social marketing), and "the efforts by organizations to produce, promote, package, and reclaim products in a manner that is sensitive or responsive to ecological concerns" (environments). Green marketing refers to marketing strategies that constitute an important part of corporate social responsibility, attract customers who are concerned about society, stimulate positive views from stakeholders, and facilitate 
corporations' triple-bottom-line accounting, thereby simultaneously contributing to the three facets of sustainability: economic prosperity, environmental quality, and social equity (Choudhary \& Gokarn, 2013; Stenzel, 2010).

Research has shown that companies could benefit from sustainable green marketing strategies that enable the development of competitive advantages in both B2C and B2B environments (Porter \& van der Linde, 1995). According to the resource-based view, competitive advantage is conceptualized as the implementation of a strategy that is currently not used by competing firms but helps "reduce costs, exploit market opportunities, and neutralize competitive threats" (Barney, 1991). Companies that can attain a competitive advantage can improve their economic performance in ways that cannot be matched by competitors (Newbert, 2008). Research has demonstrated that companies' environmental practice could be a resource and/or capability that reinforce competitive advantages (Hart, 1995). First movers who are able to adopt superior green marketing strategies can project their brand image as a sincere environmental activist, which provides the basis for a competitive advantage, as evidenced by success by pioneers like Wal-Mart (McDaniel \& Rylander, 1993).

\section{Influence of Perceived Value}

In order to investigate the positive effect of green perceived value on satisfaction, green trust, and green repurchase intention, literature relating to perceived value was investigated. Perceived value stems from the equity theory, which posits that consumers consider the ratio of their outcome/input to that of the service provider's outcome/input (Oliver \& DeSarbo, 1998). Consumers' perceived value is defined as consumers' overall assessment of what is received in relation to what is given (Zeithaml, 1988). "Green perceived value" is defined by Chen and Chang (2012) as "a consumer's overall appraisal of the net benefit of a product or service between what is received and what is given based on the consumer's environmental desires, sustainable expectations, and green needs."

Perceived value is not only an important component for long-term customer relationships, but also plays an essential role in affecting purchase intentions (Zhuang, Cumiskey, Xiao, \& Alford, 2010) and customer trust (Kim, Zhao, \& Yang, 2008). Trust is about whether someone is willing to be vulnerable based on "positive expectations of the integrity and capability of another one" (Lin, Weng, \& Hsieh, 2003). Perceived value was found to have a positive influence on customer trust and green purchase intention (Chen \& Chang, 2012). Consumer value is considered an important factor that determines satisfaction (Zeithaml, 1988). Green perceived value 
affects loyalty toward green products and impacts consumers' green trust and satisfaction; hence, it is believed to influence green perceived trust and green purchase intentions (Chen, 2010; Chen \& Chang, 2012). Therefore, the following hypotheses are proposed:

$H_{1}$ : Green perceived value is positively associated with satisfaction.

$\mathrm{H}_{2}$ : Green perceived value is positively associated with green trust.

$\mathrm{H}_{3}$ : Green perceived value is positively associated with green repurchase intention.

\section{Influence of Satisfaction and Green Trust on Green Repurchase Intention}

To investigate the determinants of green repurchase intention, green trust and satisfaction were the major factors considered. Customer satisfaction was introduced as an influential factor toward repeated purchase, higher receptiveness of other products, and positive word-of-mouth (Cardozo, 1965). Since then, customer satisfaction has been regarded as one of the essential factors for predicting consumers' purchase behavior, as many studies have shown a positive link between customer satisfaction and repurchase intentions (Zeithaml, Berry, \& Parasuraman, 1996). Satisfaction refers to consumers' expectation toward a product or service; if the product or service meets the consumers' expectation, they will be satisfied, leading to repurchase intention (Chang \& Chou, 2014). If a company is able to provide a quality product or service that satisfies or even exceeds the customers' expectation, consumers will consider repurchasing or recommending the product to others (Kotler, 1999).

Trust is believed to be the intention to accept vulnerability based on positive expectations of the behaviors or intentions of another. It has been argued that trust is a willingness to depend on another party based on the expectation resulting from the party's ability, reliability, and benevolence (Ganesan, 1994). Trust has also been found to be an important factor influencing consumers' choice of green products. Although consumers purchase green products to maintain a healthy environment, some criticisms with regard to the way such products are regulated and licensed have become apparent in the United Kingdom (Harper \& Makatouni, 2002). Green trust is defined as the "consumer's willingness to depend on a product or a service of a brand as a result of his belief in its environmental credibility, benevolence and ability" (Chen, 2013). One key element for green marketing strategy is credibility (Chen \& Chang, 2012). Researchers have shown the importance of consumer trust in influencing consumers' purchase intentions (Harris \& Goode, 2010); others have revealed that trust can significantly affect the customers' repurchase decisions (Gefen $\&$ Straub, 2004). Therefore, the resulting hypotheses are as follows: 
$H_{4}$ : Green trust is positively associated with green repurchase intention.

$\mathrm{H}_{5}$ : Satisfaction is positively associated with green repurchase intention.

The overall research framework for this study is depicted in Figure 1.

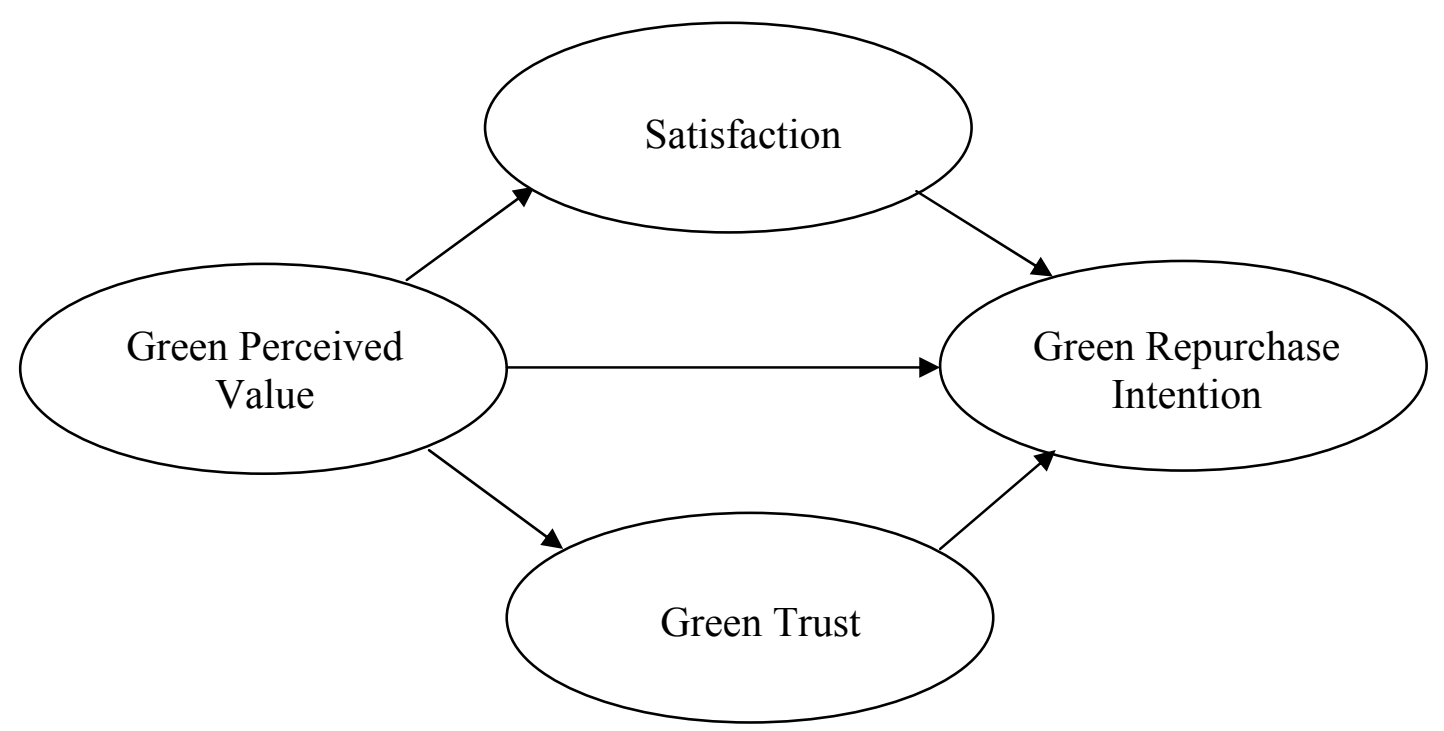

Figure 1 The Research Framework

\section{RESEARCH METHOD AND DATA ANALYSIS}

\section{Data Collection}

Green marketing is regarded as a way to achieve greater product differentiation (Aberdeen Group, 2008). Not only have automobile companies like Toyota and Ford been aggressively adopting the green strategy in manufacturing their cars, but FMCG companies like Coca-Cola, Lipton, and SC Johnson are also actively designing green products to enhance their business sustainability (Mourad \& Ahmed, 2012). In this study, the authors have chosen to consider Bonaqua, the brand of bottled water produced by Coca -Cola in Hong Kong, in an empirical study. Bonaqua is one of the top three brands in Hong Kong, together with two other local brands: Watson's and Vita. Despite fierce price competition, sales of bottled water continue to grow due to consumers' increasing health consciousness (Euromonitor International, 2012). Bonaqua was the first brand to launch a lightweight bottle in 2010, which reduced the use of plastic by a significant $34 \%$; the bottle can be twisted and shrunk to save recycling space. A research study conducted by the University of Hong Kong showed that people in Hong Kong have a high awareness (94\%) of the need for everyone in society to shoulder responsibility for environmental protection even when it involves 
inconvenience (58\%) and higher costs (64\%) (The University of Hong Kong Public Opinion Programme, 2010). In a city with such heightened awareness of the need to protect the environment, the brand chosen would be suitable for testing the response of potential green consumers.

A survey was conducted using a sample of 180 respondents who had purchased Bonaqua's lightweight bottle, and a questionnaire was developed using research instruments from the literature. The questionnaire was designed to cover the items relating to the constructs developed from the research framework for this study. For each variable relating to these measures, the respondents were asked to indicate their agreement with each statement using a seven-point Likert scale ( 1 = strongly disagree; $7=$ strongly agree). The finalized questionnaire was posted online for data collection. Purposive sampling was used in this study; we sent email invitations to 200 participants, from whom 180 completed questionnaires were successfully collected for data analysis. The response rate of the study was $90 \%$.

\section{The Measurement Model}

The PLS measurement model was evaluated by examining the convergent and discriminant validity of the individual indicator and the composite reliability of a block of indicators. Convergent validity was assessed by examining the correlation (loading) between the indicators, and the construct scores were computed using PLS techniques. The measurement scales were evaluated using the three criteria suggested by Fornell and Larcker (1981): (1) All indicator factor loadings should be significant and exceed 0.5 ; (2) composite reliability should exceed 0.7 ; and (3) average variance extracted (AVE) from each construct should exceed 0.5.

Convergent validity shows the degree to which the items of a certain instrument are related. Convergent validity can be assessed using composite reliability, AVE, and factor loading measurements. Table 1 shows the values for the loadings of the measurement model. All the reflective measures met the recommended levels for composite reliability and AVE. The composite reliabilities of the constructs ranged from 0.75 to 0.90 , with all values above the recommended level of 0.7 . These data indicate that all the items exhibit strong internal reliability. The AVE values, ranging from 0.56 to 0.82 , were greater than the variance due to measurement error and were all above the recommended value of 0.5. A confirmatory factor analysis was also conducted to test the convergent validity of each construct. The analysis showed that all the items have factor loadings higher than 0.5 in the confirmatory factor analysis (above the recommended minimum value). Furthermore, each indicator's loading was 
found to be higher than all its cross-loadings. Therefore, all the conditions for convergent validity were met.

Table 1 The Path Coefficients

\begin{tabular}{|c|c|c|c|c|c|}
\hline Constructs & Indicators & $\begin{array}{l}\text { Factor } \\
\text { Loadings }\end{array}$ & t-value & $\begin{array}{l}\text { Average } \\
\text { Variance } \\
\text { Extracted } \\
\text { (AVE) }\end{array}$ & $\begin{array}{l}\text { Composite } \\
\text { Reliability } \\
\text { (CR) }\end{array}$ \\
\hline Green Perceived & GPVALUE1 & 0.89 & 38.54 & \multirow{2}{*}{0.82} & \multirow{2}{*}{0.90} \\
\hline Value (GPVALUE) & GPVALUE2 & 0.92 & 76.42 & & \\
\hline \multirow{3}{*}{$\begin{array}{l}\text { Green Repurchase } \\
\text { Intention (GINT) }\end{array}$} & GINT1 & 0.78 & 17.76 & \multirow{3}{*}{0.56} & \multirow{3}{*}{0.79} \\
\hline & GINT2 & 0.72 & 13.77 & & \\
\hline & GINT3 & 0.74 & 16.87 & & \\
\hline \multirow{2}{*}{$\begin{array}{l}\text { Green Trust } \\
\text { (GTRUST) }\end{array}$} & GTRUST1 & 0.89 & 24.05 & \multirow{2}{*}{0.61} & \multirow{2}{*}{0.75} \\
\hline & GTRUST2 & 0.65 & 5.63 & & \\
\hline \multirow{2}{*}{ Satisfaction (SAT) } & SAT1 & 0.86 & 27.98 & \multirow{2}{*}{0.73} & \multirow{2}{*}{0.85} \\
\hline & SAT2 & 0.85 & 31.91 & & \\
\hline
\end{tabular}

A rule for assessing the discriminant validity requires that the square root of the AVE be larger than the correlations between the construct and any other construct in the model (Chin, 1998). In Table 2, the diagonal entries (in bold) represent the square root of the AVE for each construct. All other entries represent the corresponding correlation coefficients among the constructs. As shown in Table 2, all constructs met the minimum requirements. Therefore, all constructs in the model displayed adequate discriminant validity.

\section{The Structural Model}

The structural model was evaluated by examining the structural paths, $t$-statistics, and variance explained (the R-squared value). Path significances were determined by running the model using the SmartPLS statistical package through a bootstrap resampling routine with 180 cases and 1,000 bootstrap re-samples. The path coefficients for the research model are presented in Table 1. The five hypotheses presented in this study were tested using partial least square techniques. The path significance of each hypothesized association in the research model and the variance explained $\left(\mathrm{R}^{2}\right)$ by each path were examined. In Table 3 , the path coefficients with all the significant paths are highlighted with asterisks. In this study, a two-tailed $t$-test was used because independent variables may show either a positive or negative effect on the dependent variables (Helm, Eggert, \& Garnefeld, 2010). 
Table 2 The Correlation Matrix and Discriminant Validity

\begin{tabular}{lllll}
\hline Construct & $\begin{array}{l}\text { Green } \\
\text { Perceived } \\
\text { Value } \\
\text { (GPVALUE) }\end{array}$ & $\begin{array}{l}\text { Green } \\
\text { Intention } \\
\text { (GINT) }\end{array}$ & $\begin{array}{l}\text { Green Trust } \\
\text { (GTRUST) }\end{array}$ & $\begin{array}{l}\text { Satisfaction } \\
\text { (SAT) }\end{array}$ \\
$\begin{array}{l}\text { Green Perceived Value } \\
\text { (GPVALUE) }\end{array}$ & $\mathbf{0 . 9 1}$ & & & \\
\hline $\begin{array}{l}\text { Green Purchase } \\
\text { Intention (GINT) }\end{array}$ & 0.56 & $\mathbf{0 . 7 5}$ & & \\
\hline Green Trust (GTRUST) & 0.54 & 0.61 & $\mathbf{0 . 7 8}$ & $\mathbf{0 . 8 5}$ \\
\hline Satisfaction (SAT) & 0.52 & 0.51 & 0.51 & \\
\hline
\end{tabular}

Notes: 1. Diagonal entries (in bold) represent the square root of the AVE values.

\section{All other entries represent the correlation coefficients}

Satisfaction was predicted by green perceived value, which explained $27 \%\left(\mathrm{R}^{2}=\right.$ 0.27) of the variance in satisfaction, indicating a moderate R-squared value. Therefore, $H_{1}$ was supported. Green trust was predicted by green perceived value, which explained $29 \%\left(\mathrm{R}^{2}=0.29\right)$ of the variance in green trust, indicating a moderate R-squared value. Therefore, $H_{2}$ was supported. Green repurchase intention was predicted by green trust, satisfaction, and green perceived value, which explained $47 \%$ $\left(\mathrm{R}^{2}=0.47\right)$ of the variance in green repurchase intention, indicating a high overall $\mathrm{R}$ squared value. Therefore, $H_{3}, H_{4}$, and $H_{5}$ were supported.

Table 3 The Path Coefficients

\begin{tabular}{|c|c|c|c|c|c|}
\hline Path & $\beta$ & $t$ & Sig. & $\mathrm{R}^{2}$ & $\begin{array}{l}\text { Hypotheses } \\
\text { Supported }\end{array}$ \\
\hline$H_{l}$ : green perceived value $\rightarrow$ satisfaction & 0.52 & 9.46 & $* * *$ & 0.27 & Yes \\
\hline $\mathrm{H}_{2}$ : green perceived value $\rightarrow$ green trust & 0.54 & 9.01 & $* * *$ & 0.29 & Yes \\
\hline $\begin{array}{l}H_{3}: \text { green perceived value } \rightarrow \text { green } \\
\quad \text { repurchase intention }\end{array}$ & 0.27 & 3.41 & $* * *$ & \multirow{3}{*}{0.47} & Yes \\
\hline $\begin{array}{l}H_{4}: \text { green trust } \rightarrow \text { green repurchase } \\
\text { intention }\end{array}$ & 0.37 & 6.60 & $* * *$ & & Yes \\
\hline $\begin{array}{l}H_{5}: \text { Satisfaction } \rightarrow \text { green repurchase } \\
\quad \text { intention }\end{array}$ & 0.18 & 2.87 & $* *$ & & Yes \\
\hline
\end{tabular}

Note: $* * \mathrm{p}<0.01, * * * \mathrm{p}<0.001$

\section{CONCLUSIONS AND IMPLICATIONS}

The results from the study are consistent with the findings of other empirical studies in the area (Ajzen \& Fishbein, 1980; Brucks, Zeithaml, \& Naylor, 2000; Chan, 2001; Chan \& Yam, 1998; Chen \& Chang, 2012; Harris \& Goode, 2010; Schlosser, 
White, \& Lloyd, 2006; Snoj, Korda, \& Mumel, 2004; van der Heijden, Verhagen, \& Creemers, 2003; Zeithaml, 1988) and demonstrate the importance of green perceived value, green trust, and satisfaction in inducing repurchase intention.

The results of this study confirm the important contribution of green perceived value to the adoption of green products. The study demonstrated that green perceived value can directly influence the adoption of green products. It also indirectly influences green repurchase intention positively via satisfaction and green trust. This finding is consistent with the research results of other researchers on green products adoption (Chen, 2013). Furthermore, this study confirmed the influence of green perceived value on satisfaction, implying that companies have to adopt green marketing strategies to improve the green perceived value facilitated by green product features, as customer satisfaction is influenced by judgments of a product's green value. Green trust was found to be influenced by green perceived value, which is consistent with other research results (Chen \& Chang, 2012). In order to maintain the relationship with green consumers, operators need to develop the green value of a product and enhance consumers' green trust.

In this study, repurchase intention was found to be influenced by green trust, green perceived value, and satisfaction. The significance of the influence of green trust and perceived value on repurchase intention was emphasized by Chen and Chang (2012). Patterson and Spreng (1997) also agreed that a relationship exists between customers' satisfaction and repurchase intention. Therefore, the results of this study are consistent with the results from other researchers. Marketers should emphasize product greenness in order to increase consumers' repurchase intention. In addition, marketers should improve consumers' perceived green value of their products in order to raise consumers' repurchase intention. Based on the research results, the drivers of green product adoption are represented by green perceived value, green trust, and satisfaction. Companies should use more marketing resources to improve these elements in order to build up competitive advantages for the companies by enhancing green product adoption so that customers are willing to purchase them even at premium prices.

Some marketing giants have demonstrated their support of the view of this study by applying green marketing strategies. For example, Coca-Cola has been working on alleviating global water scarcity, given that water is the primary ingredient of soft drinks; in addition, Facebook declared that it aimed to reduce its "carbon footprint" by 25\% via clean energy by 2015 (Stafford \& Hartman, 2013). Marketers should focus more on creating positive perceptions of green value. Strategies promoting green trust will benefit the repurchase intention. Certifications and awards from impartial and 
credible parties could be introduced in marketing communication and public relations campaigns to induce more green trust among customers. More explicit communication in advertising, marketing collateral, and product packaging could be used to enhance the perception of the green value provided by the organization and induce green product adoption.

\section{Limitations and Future Direction of Research}

This study has some limitations that should be regarded as opportunities for future research. First, any generalization of these research results to other green products should be done cautiously, as green products are still in the initial development stage, and consumers might use different green products for different purposes and, hence, perceive their green value differently. Although the study was conducted on a product that is marketed internationally, it was still limited to a single green product, and the survey results can only be applied to the local context. Furthermore, the sample size of this study was limited to 180 Hong Kong respondents; future studies should increase the sample size to ensure a more representative sample. Future research could also include a cross-cultural study to identify cultural differences. A similar study involving different products or services might also be used to verify if the results could be generalized to the adoption of other green products. Finally, future study should replicate this study with other cultures, such as the United States and in the European Union, and with other Chinese communities, such as Taiwan and China.

\section{REFERENCES}

Aberdeen Group (2008). Going Green: when making a difference aligns with market demand, Retrieved February 10 2014, from http://www.marketingpower.com/ResourceLibrary/Documents/Content\%20Partn er\%20Documents/Aberdeen\%20Research/Going_Green.pdf

Ajzen, I., \& Fishbein, M. (1980). Understanding attitudes and predicting social behavior. . Englewood Cliffs, NJ: Prentice-Hall.

Barney, J. B. (1991). Firm resources and sustained competitive advantage. Journal of Management, 17(1), 99-120. http://dx.doi.org/10.1177/014920639101700108

Bhat, V. N. (1993). A blueprint for green product development. Industrial Management and Data Systems, 35(2), 4-7.

Brucks, M., Zeithaml, V. A., \& Naylor, G. (2000). Price and brand name as indicators of quality dimensions for consumer durables. Journal of Academy of Marketing Science, 28(3), 359-374. http://dx.doi.org/10.1177/0092070300283005 
Cardozo, R. N. (1965). An experimental study of customer effort, expectation and satisfaction. Journal of Marketing Research, 2(3), 244-249. http://dx.doi.org/10.2307/3150182

Chan, R. Y. K. (2001). Determinants of Chinese consumers' green purchase behaviour. Psychology \& Marketing, 18(4), 389-413. http://dx.doi.org/10.1002/mar.1013

Chan, R. Y. K., \& Yam, E. (1998). Green movement in a newly industrializing area: a survey on the attitudes and behaviour of the Hong Kong citizens. Journal of community and Applied Social Psychology, 5(4), 273-284. http://dx.doi.org/10.1002/casp.2450050405

Chang, S.-C., \& Chou, P.-Y. (2014). Evaluation of satisfaction and repurchase intention in online food group-buying, using Taiwan as an example. British Food Journal, 116(1), 44-61. http://dx.doi.org/10.1108/BFJ-03-2012-0058

Chen, Y. S. (2010). The Drivers of Green Brand Equity: Green Brand Image, Green Satisfaction, and Green Trust. Journal of Business Ethics, 93, 307-319. http://dx.doi.org/10.1007/s10551-009-0223-9

Chen, Y. S. (2013). Towards green loyalty: driving from green perceived value, green satisfaction, and green trust. Sustainable Development, 21(5), 294-308. http://dx.doi.org/10.1002/sd.500

Chen, Y. S., \& Chang, C. H. (2012). Enhance green purchase intentions: The roles of green perceived value, green perceived risk, and green trust. Management Decision, 50(3), 502-520. http://dx.doi.org/10.1108/00251741211216250

Chin, W. W. (1998). The partial least squares approach to structural equation modeling in: G. A. Marcoulides (Eds). In Modern Methods for Business Research (pp. 295-336). London: Lawrence Erlbaum Associates.

Choudhary, A., \& Gokarn, S. (2013). Green Marketing: a means for sustainable development. Journal of Arts, Science and Commerce, 4(3), 26-32.

Euromonitor International (2012). Bottled Water in Hong Kong, China, Retrieved February 10 2014, from http://www.euromonitor.com/bottled-water-in-hongkong-china/report

Fornell, C., \& Larcker, D. (1981). Structural equation models with unobservable variables and measurement error. Journal of Marketing Research, 18(1), 39-50. http://dx.doi.org/10.2307/3151312

Ganesan, S. (1994). Determinants of long-term orientation in buyer-seller relationships. Journal of Marketing, 58(2), 1-19. http://dx.doi.org/10.2307/1252265 
Gefen, D., \& Straub, D. (2004). Consumer trust in B2C e-commerce and the importance of social presence: experiments in e-products and e-services. Omega, 32(6), 407-424. http://dx.doi.org/10.1016/j.omega.2004.01.006

Harper, G. C., \& Makatouni, A. (2002). Consumer perception of organic food production and farm animal welfare. British Food Journal, 104(3/4/5), 287-299. http://dx.doi.org/10.1108/00070700210425723

Harris, L. C., \& Goode, M. M. H. (2010). Online servicescapes, trust, and purchase intentions. Journal of Services Marketing, 24(3), 230-243. http://dx.doi.org/10.1108/08876041011040631

Hart, S. L. (1995). A natural-resource-based view of the firm. The Academy of Management Review, 20(4), 986-1014. http://dx.doi.org/10.2307/258963

Helm, S., Eggert, A., \& Garnefeld, I. (2010). Modeling the impact of corporate reputation on customer satisfaction and loyalty using partial least squares. In W. W. C. V. E. Vinzi, J. Henseler \& H. Wang (Eds.) (Ed.), Handbook of Partial Least Squares. Heidelberg: Springer. http://dx.doi.org/10.1007/978-3-540-32827$8 \_23$

Kalafatis, S. P., Pollard, M., East, R., \& Tsogas, M. H. (1999). Green marketing and Ajzen's theory of planned behaviour: a cross-market examination. Journal of Consumer Marketing, $16(5)$ 1999. http://dx.doi.org/10.1108/07363769910289550

Kim, C., Zhao, W., \& Yang, K. H. (2008). An empirical study on the integrated framework of e-CRM in online shopping: evaluating the relationships among perceived value, satisfaction, and trust based on customers' perspectives. Journal of Electronic Commerce in Organizations, 6(3), 1-19. http://dx.doi.org/10.4018/jeco.2008070101

Koller, M., Floh, A., \& Zauner, A. (2011). Further insights into perceived value and consumer loyalty: a "green" perspective. Psychology \& Marketing, 28(12), $1154-$ 1176. http://dx.doi.org/10.1002/mar.20432

Kotler, P. (1999). Marketing Management: Analysis Planning Implementation, and Control (9th ed ed.). Upper Saddle River, NJ.: Prentice Hall.

Kotler, P., \& Armstrong, G. (2013). Principles of Marketing (15th edition ed.). New Jersey: Pearson Education.

Lin, N. P., Weng, J. C. M., \& Hsieh, Y. C. (2003). Relational bonds and customer's trust and commitment - a study on the moderating effects of web site usage. Service Industries Journal, 23(3), 103-124. http://dx.doi.org/10.1080/714005111

Makower, J. (2009). Strategies for the green economy : opportunities and challenges in the new world of business. New York: McGraw Hill. 
McDaniel, S. W., \& Rylander, D. H. (1993). Strategic green marketing. The Journal of Consumer Marketing, 10(3), 4-10. http://dx.doi.org/10.1108/07363769310041929

Mourad, M., \& Ahmed, Y. S. E. (2012). Perception of green brand in an emerging innovative market. European Journal of Innovation Management, 15(4), 514-537.

Newbert, S. L. (2008). Value, rareness, competitive advantage, and performance: a conceptual-level empirical investigation of the resource-based view of the firm. $\begin{array}{lll}\text { Strategic } \quad \text { Management } & \text { 745-768. }\end{array}$ http://dx.doi.org/10.1002/smj.686

Oliver, R. L., \& DeSarbo, W. S. (1998). Response determinants in satisfaction judgments. Journal of Consumer Research, 14(4), 495-508. http://dx.doi.org/10.1086/209131

Patterson, P., \& Spreng, R. (1997). Modeling the relationship between perceived value, satisfaction and repurchase intention in a business-to- business, service context: an empirical examination. International Journal of Service Industry Management, 8(4), 414-434. http://dx.doi.org/10.1108/09564239710189835

Peattie, P. (1998). Environmental Marketing Management: meeting the green challenge. Business Strategy and the Environment, 7(1), 52-53.

Porter, M. E., \& van der Linde, C. (1995). Green and competitive. Harvard Business Review, 73(5), 120-134.

Schlosser, A. E., White, T. B., \& Lloyd, S. M. (2006). Converting web site visitors into buyers: how web site investment increases consumer trusting beliefs and online purchase intentions. Journal of Marketing, 70(2), 133-148. http://dx.doi.org/10.1509/jmkg.70.2.133

Snoj, B., Korda, A. P., \& Mumel, A. (2004). The relationships perceived quality, perceived risk and perceived product value. Journal of Product \& Brand Management, 13(3), 156-167. http://dx.doi.org/10.1108/10610420410538050

Stafford, E. R., \& Hartman, C. L. (2013). American Marketing Association 2013, Promoting the value of sustainably minded purchase behaviours, Retrieved February $10 \quad 2014, \quad$ from

http://www.marketingpower.com/ResourceLibrary/MarketingNews/Pages/2013/1

-13/environment-purchase-behaviors-green-marketing-corporate-values.aspx

Stenzel, P. L. (2010). Sustainability, the Triple Bottom Line, and the Global Reporting Initiative. Global Edge Business Review, 4(6), 1-2.

The University of Hong Kong Public Opinion Programme (2010). Bonaqua bottled water,

Retrieved

February

10

2014 ,

from 
http://hkupop.hku.hk/english/report/pbottle10/content/resources/questionnaire.pd $\mathrm{f}$

van der Heijden, H., Verhagen, T., \& Creemers, M. (2003). Understanding online purchase intentions: contributions from technology and trust perspectives. European Journal of Information Systems, 12(1), 41-48. http://dx.doi.org/10.1057/palgrave.ejis.3000445

Whitmarsh, L. (2009). Behavioural responses to climate change: asymmetry of intentions and impacts. Journal of Environmental Psychology, 29(1), 13-23. http://dx.doi.org/10.1016/j.jenvp.2008.05.003

Zeithaml, V. A. (1988). Consumer perceptions of price, quality, and value: a meansend model and synthesis of evidence. Journal of Marketing, 52(3), 2-22. http://dx.doi.org/10.2307/1251446

Zeithaml, V. A., Berry, L. L., \& Parasuraman, A. (1996). The Behavioral Consequences of Service Quality. Journal of Marketing, 60(April), 31-46. http://dx.doi.org/10.2307/1251929

Zhuang, W., Cumiskey, K. J., Xiao, Q., \& Alford, B. L. (2010). The impact of perceived value on behavior intention: an empirical study. Journal of Global Business Management, 6(2), 1-7. 